\title{
Revegetation of Medusahead-Invaded Sagebrush Steppe
}

\author{
Kirk W. Davies \\ Author is Rangeland Scientist, US Department of Agriculture-Agricultural Research Service at the Eastern Oregon Agricultural Research Center, \\ Burns, OR 97720, USA.
}

\begin{abstract}
Medusahead (Taeniatherum caput-medusae [L.] Nevski) is an exotic annual grass invading western rangelands. Invasion by medusahead is problematic because it decreases livestock forage production, degrades wildlife habitat, reduces biodiversity, and increases fire frequency. Revegetation of medusahead-invaded sagebrush steppe is needed to increase ecosystem and economic productivity. Most efforts to revegetate medusahead-infested plant communities are unsuccessful because perennial bunchgrasses rarely establish after medusahead control. The effects of prescribed burning (spring or fall), fall imazapic application, and their combinations were evaluated for medusahead control and the establishment of seeded large perennial bunchgrasses. One growing season after treatments were applied, desert wheatgrass (Agropyron desertorum [Fisch. ex Link] Schult.) and squirreltail (Elymus elymoides [Raf.] Swezey) were drill seeded into treatment plots, except for the control treatment. Vegetation characteristics were measured for $2 \mathrm{yr}$ postseeding (second and third year post-treatment). Medusahead was best controlled when prescribed burned and then treated with imazapic $(P<0.05)$. These treatments also had greater large perennial bunchgrass cover and density compared to other treatments $(P<0.05)$. The prescribed burned followed by imazapic application had greater than 10 - and 8 -fold more perennial bunchgrass cover and density than the control treatment, respectively. Prescribed burning, regardless of season, was not effective at controlling medusahead or promoting establishment of perennial bunchgrasses. The results of this study question the long-term effectiveness of using imazapic in revegetation efforts of medusahead-infested sagebrush steppe without first prescribed burning the infestation. Effective control of medusahead appears to be needed for establishment of seeded perennial bunchgrasses. The results of this study demonstrate that seeding desert wheatgrass and squirreltail can successfully revegetate rangeland infested with medusahead when medusahead has been controlled with prescribed fire followed by fall application of imazapic.
\end{abstract}

\section{Resumen}

Taeniatherum caput-medusae (L.) Nevski es una gramínea anual exótica que está invadiendo los pastizales del oeste de los Estados Unidos. La invasión por esta especie es problemática porque genera una reducción en la producción de forraje para el ganado, degrada el hábitat para la fauna silvestre, genera una reducción en la biodiversidad, y promueve un incremento en la frecuencia de fuegos. La revegetación de estepas de Artemisia tridentata invadidas por T. caput-medusae es necesaria a fin de incrementar la productividad biológica y económica del ecosistema. La mayoría de los esfuerzos para revegetar comunidades vegetales invadidas por T. caput-medusae fracasan dado que las gramíneas perennes nativas rara vez se establecen luego del control de este especie invasora. Se evaluaron los efectos de quemas prescriptas (primavera u otoño), aplicación de un herbicida en otoño (imazapic), y la combinación de ambas sobre el control de T. caput-medusae y el establecimiento de gramíneas altas perennes sembradas. Una temporada luego de la aplicación de los tratamientos se sembraron Agropyron desertorum (Fisch. ex Link) Schult y Elymus elymoides (Raf.) Swezey en las parcelas tratadas exceptuando el control. Las características de la vegetación se midieron en el segundo y tercer año post-tratamiento. El mejor control de T. caput-medusae se logró en las parcelas que recibieron quema prescripta seguida de imazapic $(P<0.05)$. Estos tratamientos también tuvieron mayor cobertura y densidad de gramíneas altas perennes comparado con los otros tratamientos $(P<0.05)$. El tratamiento de quema prescripta seguida de la aplicación de imazapic tuvo 10 y 8 veces más cobertura y densidad de gramíneas perennes, respectivamente, que las parcelas de control. La quema prescripta en cualquiera de las dos temporadas ensayadas no fue efectiva en el control de $T$. caput-medusae ni en el establecimiento de gramíneas perennes nativas. Los resultados de este ensayo cuestionan la efectividad de largo plazo del uso de imazapic sin una quema prescripta previa en proyectos de revegetación de estepas de A. tridentata invadidos por T. caput-medusae. Aparentemente, es necesario el control efectivo de T. caput-medusae para lograr el establecimiento de gramíneas perennes sembradas. Los resultados de este ensayo demuestran que se pueden revegetar exitosamente pastizales invadidos por T. caput-medusae mediante la siembra de Agropyron desertorum y Elymus elymoides cuando el T. caput-medusae es controlado con una quema prescripta seguida de una aplicación de imazapic.

Key Words: annual grass invasion, fire-herbicide control, invasive plants, prescribed burning, sagebrush community restoration, Taeniatherum caput-medusae

Mention of a proprietary product does not constitute a guarantee or warranty of the product by USDA, Oregon State University, or the authors and does not imply its approval to the exclusion of other products.

Correspondence: US Department of Agriculture-Agricultural Research Service, Eastern Oregon Agricultural Research Center, 67826-A Hwy 205, Burns, OR 97720, USA. Email: kirk. davies@oregonstate.edu

Manuscript received 2 October 2009; manuscript accepted 16 June 2010

\section{INTRODUCTION}

Exotic annual grass invasions are problematic in arid and semiarid plant communities (Mack 1981; D'Antonio and Vitousek 1992; Liu et al. 2006; Davies and Svejcar 2008). Invasion by exotic grasses often increases fire frequency, which negatively impacts native plant communities (Torell et al. 1961; Whise- 
nant 1990; Hughes et al. 1991; D'Antonio and Vitousek 1992; Brooks et al. 2004). Medusahead (Taeniatherum caputmedusae [L.] Nevski) is an aggressive exotic annual grass that decreases biodiversity, degrades wildlife habitat, reduces livestock forage production, and increases fine fuel loads (Davies and Svejcar 2008). Medusahead effectively competes with native vegetation allowing it to invade and dominate plant communities (Hironaka and Sindelar 1975; Goebel et al. 1988; James et al. 2008; Young and Mangold 2008). Litter accumulation from medusahead also suppresses other plants and can increase wildfire frequency (Torrell et al. 1961; Davies and Svejcar 2008).

Medusahead invasion is especially serious because many efforts to revegetate infested rangeland are unsuccessful (Young 1992; Monaco et al. 2005). Short-term control of medusahead has been accomplished with various treatments. Prescribed burning has been moderately successful to completely unsuccessful at controlling medusahead depending on fire and site characteristics (Murphy and Lusk 1961; Young et al. 1972; Kyser et al. 2008; Davies and Sheley, in press). Herbicides have been reported to control medusahead for one or two years (Monaco et al. 2005; Kyser et al. 2007; Davies and Sheley, in press). Integrating burning and herbicide treatments often improves medusahead control. For example, the control of medusahead with imazapic has been reported to be improved when the infestation is first prescribed burned (Monaco et al. 2005; Kyser et al. 2007; Sheley et al. 2007; Davies and Sheley, in press). However, without establishment of desirable plants, medusahead soon regains dominance of the plant community (Young 1992; Monaco et al. 2005; Sheley et al. 2007).

For successful revegetation of medusahead-infested plant communities, effective control of medusahead must be coupled with the establishment of competitive desirable vegetation. Establishment of large perennial bunchgrasses is critical because they are the most competitive plant functional group with medusahead (Davies 2008; James et al. 2008). Desert wheatgrass (Agropyron desertorum [Fisch. ex Link] Schult.) and squirreltail (Elymus elymoides [Raf.] Swezey) were selected to be seeded after medusahead control treatments because of their competitive abilities and success at establishing. Desert wheatgrass establishes well (Hull 1974; Eiswerth et al. 2009) and is competitive for soil resources with other plants (Cook 1965; Caldwell et al. 1985; Eissenstat and Caldwell 1987). Squirreltail has rapid phenological development, compared to other native perennial bunchgrasses, and can establish in medusahead infestations (Hironaka and Tisdale 1963; Hironaka and Sindelar 1973). Squirreltail is a promising candidate to revegetate medusahead infestations (Jones 1998). In a greenhouse study, Young and Mangold (2008) demonstrated that squirreltail seedlings were not effective competitors with medusahead. However, Clausnitzer et al. (1999) reported that established squirreltail individuals compared to seedlings were more competitive with medusahead.

The objective of this study was to compare the effectiveness of prescribed burning, imazapic application, and their combinations for controlling medusahead and establishing perennial bunchgrasses. I hypothesized that 1) combinations of imazapic and prescribed burning would be the most effective treatments at controlling medusahead and increasing desired vegetation, and 2) imazapic application would be required (either with or without burning) to effectively control medusahead and promote desired vegetation. I speculated that effective control of medusahead would be required for successful establishment of perennial bunchgrasses because medusahead is an effective competitor (Hironaka and Sindelar 1975; Goebel et al. 1988; James et al. 2008; Young and Mangold 2008).

\section{METHODS}

\section{Study Sites}

The study sites were located between Riddle Mountain and Diamond Valley in southeast Oregon about $65 \mathrm{~km}$ southeast of Burns, OR. Elevation of the study sites ranges from 1300 to $1500 \mathrm{~m}$ above sea level. Topography was variable and included ridge tops, side slopes, shoulder slopes, and flats. Slopes are between $2^{\circ}$ and $21^{\circ}$ and aspect ranges from south to northeast. Soils are a complex of different series with $20 \%$ to $35 \%$ clay content and moderate to high shrink-swell potential (Natural Resource Conservation Service 2008). Long-term average annual precipitation was between $250 \mathrm{~mm}$ and $300 \mathrm{~mm}$ (Oregon Climatic Service 2009). Regional precipitation was $66 \%, 80 \%$, and $110 \%$ of the long-term average in the 2007 , 2008, and 2009 crop-year (effective precipitation for plant growth), respectively (Oregon Climatic Service 2009; Eastern Oregon Agricultural Experiment Center, unpublished data, 2009). The sites were formerly Wyoming big sagebrush (Artemisia tridentata subsp. wyomingensis [Beetle \& A. Young] S. L. Welsh) and low sagebrush (Artemisia arbuscula Nutt.)bunchgrass steppe. Study sites at the initiation of this experiment were near-monocultures of medusahead. The study occurred on Loamy 10-12PZ and Claypan 12-16PZ rangeland ecological sites (Natural Resource Conservation Service 2008). Three study sites were located on each of the rangeland ecological sites. Characteristic vegetation for the Loamy 10$12 \mathrm{PZ}$ rangeland ecological site is Wyoming big sagebrush, bluebunch wheatgrass (Pseudoroegneria spicata [Pursh] A. Löve,), and Thurber's needlegrass (Achnatherum thurberianum [Piper] Barkworth; Natural Resource Conservation Service 2008). Characteristic vegetation for the Claypan 12-16PZ rangeland ecological site is low sagebrush, Idaho fescue (Festuca idahoensis Elmer), bluebunch wheatgrass, and Sandberg bluegrass (Poa secunda J. Presl; Natural Resource Conservation Service 2008). Prior to the implementation of the study, cattle grazed the study sites every other year for the past $16 \mathrm{yr}$. During the study livestock were excluded with temporary fences.

\section{Experimental Design and Measurements}

A randomized complete block design was used to evaluate the effects of treatments on vegetation characteristics. Six sites (blocks) invaded by medusahead with varying soils, potential natural vegetation, slope, and aspect were selected. Each block consisted of seven $5 \times 5 \mathrm{~m}$ plots randomly assigned to the various treatments with 1 -m buffers between treatments. Prior to treatment, vegetation cover and density were similar among plots assigned the various treatment $(P>0.05)$, but differed among sites $(P<0.05)$. Treatments were 1$)$ imazapic applied in the fall (Imazapic), 2) spring prescribed burn and imazapic (Spring Burn-Imazapic), 3) fall prescribed burn and imazapic (Fall Burn-Imazapic), 4) spring prescribed burn (Spring Burn), 
5) fall prescribed burn (Fall Burn), 6) control seeded (ControlSeeded), and 7) control (Control).

All treatments, excluding the Control treatment, were drillseeded with desert wheatgrass and squirreltail in late September of 2007 . Both species were seeded at $9 \mathrm{~kg} \cdot \mathrm{ha}^{-1}$ percent live seed (PLS) for a total of $18 \mathrm{~kg} \cdot \mathrm{ha}^{-1}$ PLS, simultaneously using a Versa-Drill (Kasco, Inc, Shelbyville, IN). Seeds were mixed together and thus, both species were seeded into the same drill rows. Row spacing, measured from the center of the drill row to the center of the next drill row, was $23 \mathrm{~cm}$. Perennial bunchgrasses were seeded one full growing season after medusahead control treatments were applied because imazapic would probably prevent or at least significantly reduce the establishment of seeded species in the first growing season postapplication.

Spring and fall burns were applied in mid-May and midOctober of 2006, respectively. Burns were strip-head fires ignited with drip-torches. Fuels loads ranged from 1280 to $2450 \mathrm{~kg} \cdot \mathrm{ha}^{-1}$, and fuel moisture varied between $35 \%$ and $54 \%$ during the spring burns depending on site. Wind speeds during the spring burns varied between $1 \mathrm{~km} \cdot \mathrm{h}^{-1}$ and $8 \mathrm{~km} \cdot \mathrm{h}^{-1}$, temperature ranged from $18^{\circ} \mathrm{C}$ to $22^{\circ} \mathrm{C}$, and relative humidity was between $28 \%$ and $35 \%$. Spring burning removed $90 \%$ to $94 \%$ of the medusahead litter and resulted in $96 \%$ to $98 \%$ reduction in medusahead density for the rest of the growing season. In the fall burns, fuel loads were between 1200 and $2360 \mathrm{~kg} \cdot \mathrm{ha}^{-1}$, and fuel moisture ranged from $11 \%$ to $16 \%$. Wind speeds were $2 \mathrm{~km} \cdot \mathrm{h}^{-1}$ to $10 \mathrm{~km} \cdot \mathrm{h}^{-1}$, temperature was between $7^{\circ} \mathrm{C}$ and $13^{\circ} \mathrm{C}$, and relative humidity was $38 \%$ to $65 \%$. Fall burning removed $92 \%$ to $98 \%$ of the medusahead litter. After the fall prescribed burns were completed, imazapic (Plateau; BASF Corporation, Research Triangle Park, NC) was applied at a rate of $87.5 \mathrm{~g}$ ai $\cdot \mathrm{ha}^{-1}$ in mid-October of 2006 with a 10 -foot $(3.05-\mathrm{m})$ handheld $\mathrm{CO}_{2}$ sprayer $(\mathrm{R} \& \mathrm{D}$ Sprayers, Opelousas, LA) with a tank pressure of $206.8 \mathrm{kPa}$. During imazapic application, wind speeds were $1 \mathrm{~km} \cdot \mathrm{h}^{-1}$ to $5 \mathrm{~km} \cdot \mathrm{h}^{-1}$ and air temperatures were between $12^{\circ} \mathrm{C}$ and $14^{\circ} \mathrm{C}$. No precipitation occurred during application, and the next precipitation event $(4 \mathrm{~mm})$ occurred $10 \mathrm{~d}$ postapplication.

Vegetation characteristics were sampled in mid-June of 2008 and 2009. Herbaceous cover and density were measured by species in sixteen $40 \times 50 \mathrm{~cm}$ frames $\left(0.2 \mathrm{~m}^{2}\right)$ per plot. Litter cover and bare ground were also measured in each of the sixteen $40 \times 50 \mathrm{~cm}$ frames per plot. Cover was visually estimated in the $40 \times 50 \mathrm{~cm}$ frames. The $40 \times 50 \mathrm{~cm}$ frames were divided into $1 \%, 5 \%, 10 \%, 25 \%$, and $50 \%$ segments to make cover estimation easier and more accurate. The $40 \times$ $50 \mathrm{~cm}$ frames were located at $1-\mathrm{m}$ intervals on four $5-\mathrm{m}$ transects (starting at $1 \mathrm{~m}$ and ending at $4 \mathrm{~m}$ ), resulting in four frames per transect. The $5-\mathrm{m}$ transects were deployed at $1-\mathrm{m}$ intervals in each plot. Herbaceous vegetation diversity (Shannon diversity index) was calculated from plant density measurements (Krebs 1998).

\section{Statistical Analysis}

To determine the effects of treatments on vegetation characteristics, repeated measures analysis of variance with years as the repeated factor was used to analyze the data using the PROC MIX method in SAS version 9.1 (SAS Institute Inc.,
Cary, NC). Fixed variables were treatments and random variables were site and site by treatment interactions. The appropriate covariance structures were determined by using the Akaike's Information Criterion (Littell et al. 1996). Treatment means were separated using Fisher's protected LSD $(P<0.05)$ and reported with standard errors (mean $+S E)$. For analyses, herbaceous cover and density were grouped into five functional groups: large perennial bunchgrasses, Sandberg bluegrass, perennial forbs, annual forbs, and exotic annual grasses (largely comprised of medusahead). Sandberg bluegrass was classified as a separate functional group because of its relatively small stature and early development compared to other perennial bunchgrasses in these plant communities (Davies 2008; James et al. 2008). Plant functional groups are a common and practical method of classifying plant species into groups based on physiological and morphological characteristics (Lauenroth et al. 1978; Davies et al. 2007b). Vegetation was also analyzed as total perennial herbaceous (sum of perennial herbaceous vegetation) and total herbaceous vegetation (sum of all herbaceous vegetation).

\section{RESULTS}

\section{Cover}

Large perennial bunchgrass cover varied by treatment, and the interaction between treatment and year was significant (Fig. 1A; $P<0.01$ ). The Fall Burn-Imazapic and Spring BurnImazapic treatments increased large perennial bunchgrass cover more than the other treatments $(P<0.05)$. Both treatments had greater than 10-fold more perennial bunchgrass cover in 2009 than the Control and Control-Seeded treatments. The Imazapic treatment had greater perennial grass cover than the Spring Burn, Fall Burn, Control, and Control-Seeded treatments $(P<0.05)$. The Spring Burn, Fall Burn, Control, and ControlSeeded treatments did not differ in perennial bunchgrass cover $(P>0.05)$. The Fall Burn-Imazapic and Spring Burn-Imazapic treatments increased in perennial bunchgrass cover from 2008 to 2009, while the other treatments did not $(P<0.01)$.

Total perennial herbaceous cover varied by treatment (Fig. 1B; $P<0.01$ ), but the interaction of treatment and year was not significant $(P=0.65)$. The Fall Burn-Imazapic and Spring Burn-Imazapic treatments had more total perennial herbaceous cover than the other treatments $(P<0.05)$. In 2009 the Fall Burn-Imazapic and Spring Burn-Imazapic treatments had more than fourfold more total perennial herbaceous cover than the Control and Control-Seeded treatments. Perennial herbaceous cover was more than twofold greater in the Fall Burn-Imazapic and Spring Burn-Imazapic treatments compared to the Spring Burn and Fall Burn treatments in 2009. The Imazapic treatment had greater total perennial herbaceous cover than the Fall Burn, Spring Burn, Control, and ControlSeeded treatments $(P<0.05)$.

Exotic annual grass cover (largely comprised of medusahead with some cheatgrass (Bromus tectorum L.) varied by treatment (Fig. 1C; $P<0.01$ ), but the interaction between treatment and year was not significant $(P=0.64)$. The Fall Burn-Imazapic and Spring Burn-Imazapic treatments reduced annual grass cover more than the other treatments $(P<0.05)$. These treatments generally had less than half the exotic annual 


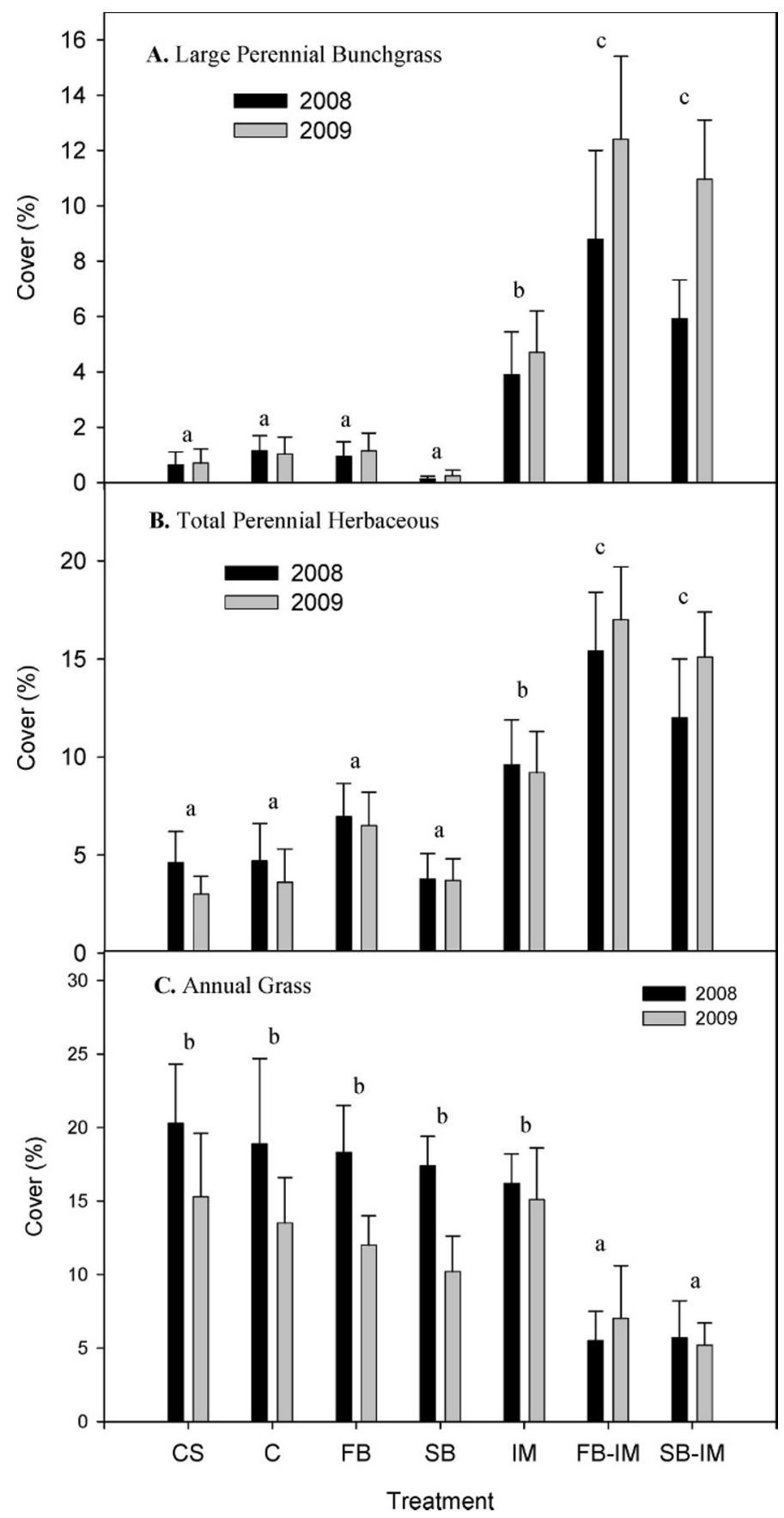

Figure 1. A, Large perennial bunchgrass, B, total perennial herbaceous, and $\mathbf{C}$, exotic annual grass cover values (mean $+\mathrm{SE}$ ) in the various medusahead control treatments in 2008 and 2009. Treatments are $\mathrm{CS}=$ control and seeded, $\mathrm{C}=$ control, $\mathrm{FB}=$ prescribed fall burn, $\mathrm{SB}=$ prescribed spring burn, $\mathrm{IM}=$ fall imazapic application $\left(87.5 \mathrm{~g}\right.$ ai $\left.\cdot \mathrm{ha}^{-1}\right)$, FB-IM = prescribed fall burn followed with fall imazapic application, and SB-IM = prescribed spring burn followed with fall imazapic application. Desert wheatgrass (Agropyron desertorum [Fisch. ex Link] Schult.) and squirreltail (Elymus elymoides [Raf.] Swezey) were drill-seeded into all the treatments except the control one growing season post-treatment. Different lower case letters indicate differences between treatments after treatment application across years $(P<0.05)$.

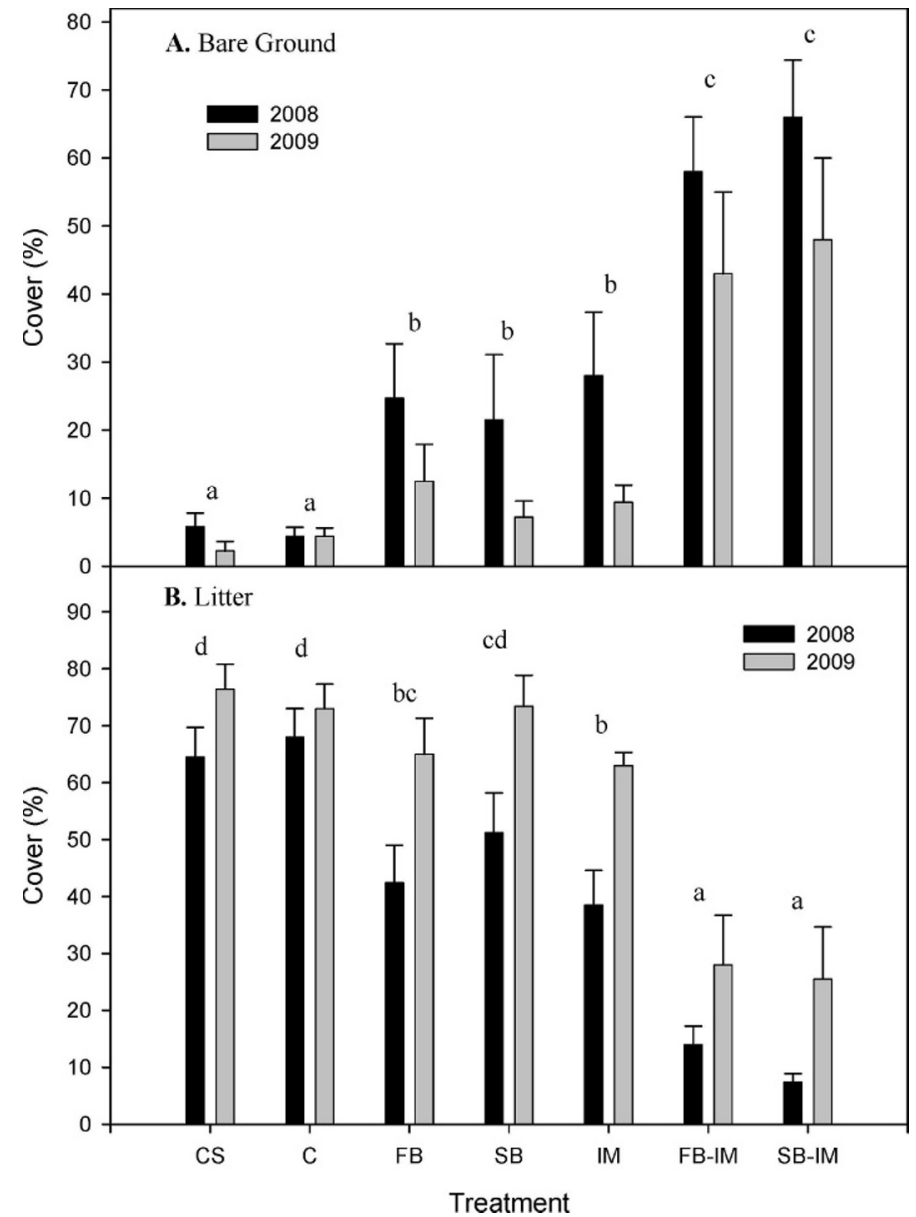

Figure 2. $\mathbf{A}$, bare ground, and $\mathbf{B}$, litter cover values (mean $+\mathrm{SE}$ ) in the various medusahead control treatments in 2008 and 2009. Treatments are $\mathrm{CS}=$ control and seeded, $\mathrm{C}=$ control, $\mathrm{FB}=$ prescribed fall burn, $\mathrm{SB}=$ prescribed spring burn, $\mathrm{IM}=$ fall imazapic application $\left(87.5 \mathrm{~g} \mathrm{ai} \cdot \mathrm{ha}^{-1}\right)$, FB-IM = prescribed fall burn followed with fall imazapic application, and SB-IM = prescribed spring burn followed with fall imazapic application. Desert wheatgrass (Agropyron desertorum [Fisch. ex Link] Schult.) and squirreltail (Elymus elymoides [Raf.] Swezey) were drill-seeded into all the treatments except the control one growing season post-treatment. Different lower case letters indicate differences between treatments after treatment application across years $(P<0.05)$.

grass cover compared to the other treatments. Annual grass cover did not vary among the other treatments $(P>0.05)$. Sandberg bluegrass, annual forb, perennial forb, and total herbaceous cover did not vary by treatment, and the interaction between treatment and year was not significant $(P>0.05)$.

Bare ground and litter cover varied by treatment (Fig. 2; $P<0.01$ ), but the interaction between treatment and year was not significant $(P=0.20$ and 0.39 , respectively). Bare ground was highest in the Fall Burn-Imazapic and Spring BurnImazapic treatments $(P<0.01)$. The Imazapic, Fall Burn, and Spring Burn also had more bare ground than the Control and Control-Seeded treatments $(P<0.05)$. The Fall Burn-Imazapic and Spring Burn-Imazapic treatments had less litter than the other treatments $(P<0.01)$. The Imazapic and Fall Burn had less litter than the Control and Control-Seeded treatments $(P<0.05)$. The Spring Burn did not differ in litter cover from 


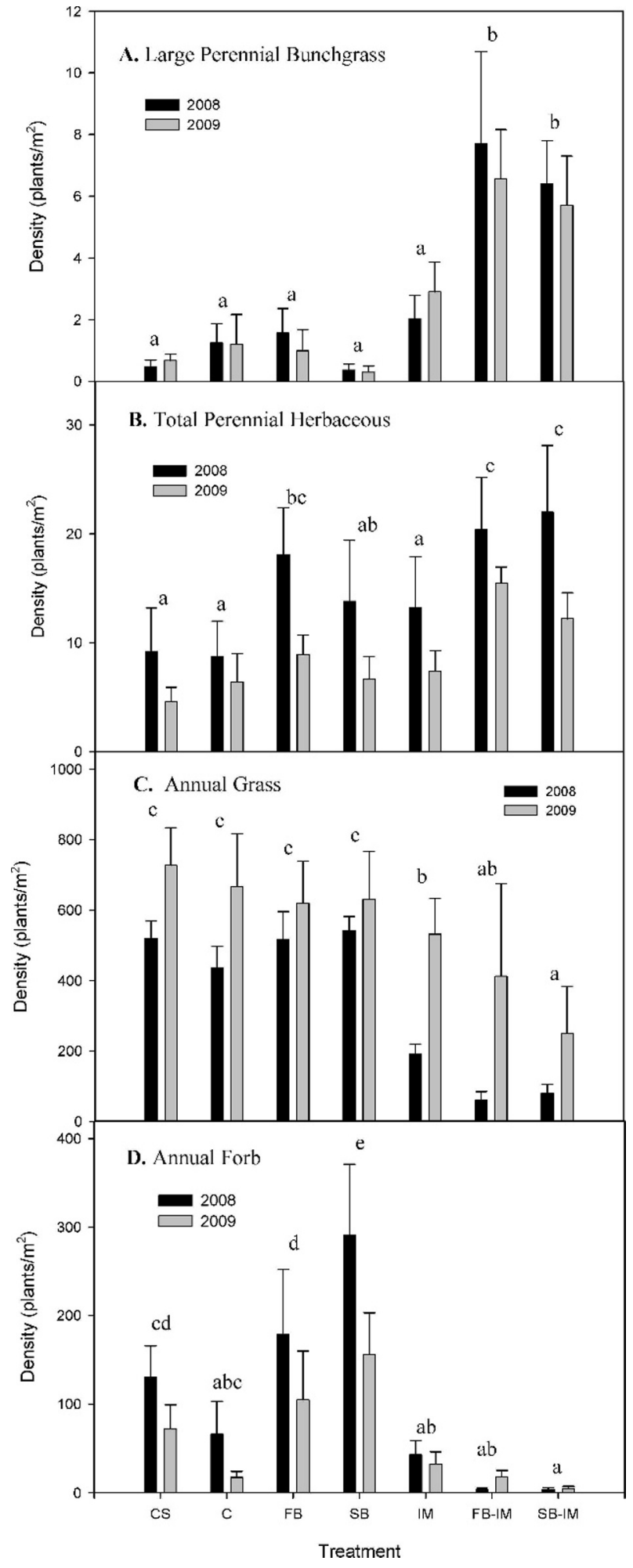

Figure 3. A, Large perennial bunchgrass, B, total perennial herbaceous, $\mathbf{C}$, exotic annual grass, and $\mathbf{D}$, annual forb densities (mean $+\mathrm{SE}$ ) in the various medusahead control treatments in 2008 and 2009. Treatments are $\mathrm{CS}=$ control and seeded, $\mathrm{C}=$ control, $\mathrm{FB}=$ prescribed fall burn, $S B=$ prescribed spring burn, $I M=$ fall imazapic application (87.5 $\mathrm{g} \mathrm{ai} \cdot \mathrm{ha}^{-1}$ ), FB-IM = prescribed fall burn followed with fall imazapic application, and SB-IM = prescribed spring burn followed with fall imazapic application. Desert wheatgrass (Agropyron desertorum [Fisch. ex Link] Schult.) and squirreltail (Elymus elymoides [Raf.] the Control-Seeded and Control treatments $(P=0.15$ and 0.14 , respectively).

\section{Density and Diversity}

Large perennial bunchgrass density varied by treatment (Fig. 3A; $P<0.01)$, but the interaction between treatment and year was not significant $(P=0.72)$. Perennial bunchgrass density was greatest in the Fall Burn-Imazapic and Spring Burn-Imazapic treatments $(P<0.01)$. In 2009 the Fall Burn-Imazapic treatment had approximately 10 -fold and 8 -fold higher perennial bunchgrass density than the Control-Seeded and Control treatments, respectively. Perennial bunchgrass density was about eightfold and sevenfold greater in the Spring Burn-Imazapic treatment compared to the Control-Seeded and Control treatments, respectively. Large perennial bunchgrass density did not vary among the other treatments $(P>0.05)$. In $2008,76 \%$ and $24 \%$ of the seeded perennial bunchgrasses were squirreltail and desert wheatgrass, respectively. In $2009,40 \%$ and $60 \%$ of the seeded perennial bunchgrasses were squirreltail and desert wheatgrass, respectively.

Total perennial herbaceous density varied by treatment (Fig. 3B; $P<0.01$ ), but the interaction between year and treatment was not significant $(P=0.87)$. The Fall BurnImazapic and Spring Burn-Imazapic treatments had greater total perennial herbaceous density than the other treatments $(P<0.05)$, except for the Fall Burn treatment $(P=0.12$ and 0.19 , respectively). The Fall Burn treatment had higher total perennial herbaceous density than the Control-Seeded and Control treatments $(P=0.02$ and 0.04 , respectively). Total perennial herbaceous densities in the Imazapic and Spring Burn treatments did not differ from the Control and Control-Seeded treatments $(P>0.05)$.

Exotic annual grass density varied by treatment (Fig. 3C; $P<0.01)$, but interaction between year and treatment was not significant $(P=0.83)$. Annual grass density was the least in the Fall Burn-Imazapic and Spring Burn-Imazapic treatments $(P<0.05)$. In 2009 the Spring Burn-Imazapic had approximately threefold less exotic annual grass than the Control and Control-Seeded treatment. The Imazapic treatment also had lower annual grass density than the Control and ControlSeeded treatments $(P<0.05)$. The Spring Burn and Fall Burn treatments did not differ in annual grass density from the Control and Control-Seeded treatments $(P>0.05)$.

Annual forb density varied among the treatments (Fig. 3D; $P<0.01)$ and the treatment by year interaction was not significant $(P=0.31)$. The Spring Burn had the greatest annual forb density of all the treatments $(P<0.05)$. The Spring BurnImazapic generally had the lowest annual forb density $(P<0.05)$. The application of imazapic with or without burning generally decreased annual forb density. Sandberg bluegrass and perennial forb densities did not differ among treatment and the interaction between treatment and year was not significant $(P>0.05)$.

\section{$\leftarrow$}

Swezey) were drill-seeded into all the treatments except the control one growing season post-treatment. Different lowercase letters indicate differences between treatments after treatment application across years $(P<0.05)$. 


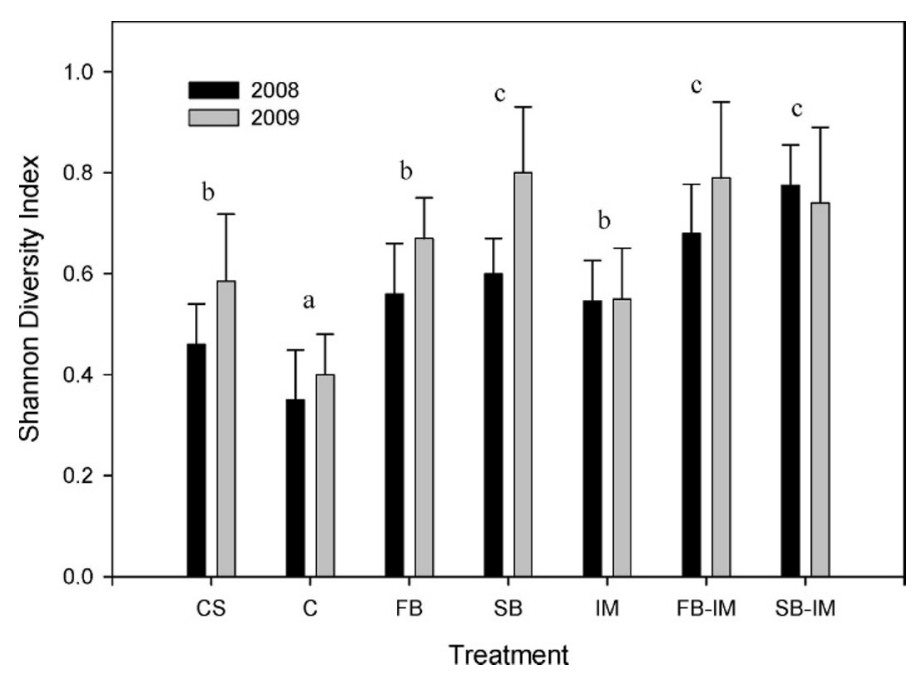

Figure 4. Shannon diversity index (mean + SE) in the various medusahead control treatments in 2008 and 2009. Treatments are $\mathrm{CS}=$ control and seeded, $\mathrm{C}=$ control, $\mathrm{FB}=$ prescribed fall burn, $\mathrm{SB}=$ prescribed spring burn, $\mathrm{IM}=$ fall imazapic application (87.5 $\left.\mathrm{g} \mathrm{ai} \cdot \mathrm{ha}^{-1}\right)$, FB-IM = prescribed fall burn followed with fall imazapic application, and SB-IM = prescribed spring burn followed with fall imazapic application. Desert wheatgrass (Agropyron desertorum [Fisch. ex Link] Schult.) and squirreltail (Elymus elymoides [Raf.] Swezey) were drill-seeded into all the treatments except the control one growing season post-treatment. Different lowercase letters indicate differences between treatments after treatment application across years $(P<0.05)$

Plant diversity varied among the treatments (Fig. 4; $P<0.01$ ), but was not influenced by the interaction between year and treatment $(P=0.80)$. Plant diversity was generally greater in the Spring Burn, Spring Burn-Imazapic, and Fall Burn-Imazapic treatments. Plant diversity in the Fall Burn and Imazapic treatments were not different from the ControlSeeded treatment $(P=0.17$ and 0.70 , respectively).

\section{DISCUSSION}

Effective medusahead control combined with seeding competitive desirable perennial bunchgrasses can revegetate medusahead-invaded sagebrush steppe. However, the effectiveness of treatments at controlling medusahead and promoting seeded perennial bunchgrasses varies considerably among the treatments. The results suggest that effective control of medusahead is required to establish perennial bunchgrasses. The results also question the effectiveness of individual treatments, compared to combinations of treatments, at effectively controlling medusahead and promoting the establishment of perennial bunchgrasses.

Treatments varied in their effectiveness at controlling medusahead and promoting the establishment of large perennial bunchgrasses largely based on whether or not they were applied as individual treatments or as combinations of burning and imazapic. Control of medusahead was most successful with combinations of prescribed burning and imazapic application. Davies and Sheley (in press), Monaco et al. (2005), and Kyser et al. (2007) also reported that prescribed burning prior to imazapic application increased the control of medusahead. Fire can increase the effectiveness of herbicides by removing litter thereby increasing the contact between the herbicide and vegetation target (DiTomaso et al. 2006). Burning may also increase the site availability, thus promoting establishment of seeded species. Davies et al. (2007a) reported an increase in soil inorganic nitrogen following prescribed burning in Wyoming big sagebrush plant communities. Spring burning probably also reduced the medusahead seed production by controlling medusahead prior to seed development. However, prescribed burning, regardless of season, without imazapic application did not control medusahead.

Treatments that effectively controlled medusahead had better perennial bunchgrass establishment. Prescribed burning followed by imazapic application more than tripled the density of large perennial bunchgrasses compared to applying imazapic without first burning. The success of the prescribed burning followed by imazapic application treatments in establishing large perennial bunchgrasses in medusahead infestations is contrary to the difficulty reported in establishing perennial bunchgrasses in exotic annual grass infestations (e.g., Young 1992; Rafferty and Young 2002; Milton 2004; Monaco et al. 2005). Contrasting reports are likely due to site, plant species, and climatic differences among studies. Treatments in this study that did not effectively control medusahead had very low perennial grass density and cover. The competitiveness of medusahead (Hironaka and Sindelar 1975; Goebel et al. 1988; James et al. 2008; Young and Mangold 2008) probably prevents desired plants from establishing when medusahead is not effectively controlled. Thus, overcoming the limited availability of desired species (i.e., seeding desired plants) in medusahead infestations, without effectively controlling medusahead, will probably not be sufficient to increase desired vegetation.

The large perennial grass densities in the areas prescribed burned followed by imazapic applications were more than half the average density reported in Davies and Bates (2010) for intact Wyoming big sagebrush plant communities. A higher density would have been desirable, but achieving half the density of intact stands is a significant accomplishment toward revegetation. Especially considering that the ability of medusahead to establish decreases rapidly as large perennial bunchgrass density increases (Davies 2008), and that the large perennial bunchgrass densities were increased between $700 \%$ and $1000 \%$ with the burning followed by imazapic treatments compared to untreated medusahead plots.

The results suggest that solely applying imazapic will not be an effective long-term treatment for the control of medusahead and establishment of desired vegetation. The Imazapic treatment had greater perennial bunchgrass cover than the Control and Control-Seeded treatments, but perennial bunchgrass density did not differ. Medusahead was also rapidly recovering in the Imazapic treatment (Fig. 3C), further suggesting that Imazapic treatment alone was not effective. Without significant increases in perennial bunchgrass density, it is doubtful that the Imazapic treatment alone will be successful. Establishing large perennial bunchgrasses is especially critical because they dominate the herbaceous understory in intact sagebrush plant communities (Davies et al. 2006) and are the most important plant functional group for preventing medusahead establishment (Davies 2008). Medusahead rapidly regains dominance of 
plant communities when establishment of desired vegetation is unsuccessful (Young 1992; Monaco et al. 2005).

Though imazapic was required for successful control of medusahead and establishment of perennial bunchgrasses, it appears to slightly negatively impact annual forbs. A short-term decrease in annual forbs density is expected when using a preemergence herbicide because of the similarities in life cycles between annual forbs and exotic annual grasses (Davies and Sheley, in press). The results suggest that by the third growing season postapplication imazapic effects on annual forbs were subsiding. This is ecologically significant because forbs are a critical component of these plant communities (Davies et al. 2006; Davies and Bates 2010) and are nutritious forage for wildlife (Gregg et al. 2008). Preserving the annual forb component would also be critical to maintaining plant functional group diversity. Diversity of plant functional groups is important to ensure spatial and temporal use of available soil resources, thus preempting their use by exotic plants (Davies et al. 2007b).

Plant diversity was increased by all treatments compared to the control. However, diversity was generally greatest when prescribed burning and imazapic applications were combined, with the exception of the Spring Burn treatment. The Spring Burn treatment promoted a large annual forb response (Fig. 3D) that was probably the driving factor in its increase in diversity, while the increase in diversity in the Fall BurnImazapic and Spring Burn-Imazapic treatments was associated with increased perennial vegetation (Fig. 3B). Effective control of medusahead promoted plant diversity, but was not required as evidenced by the Spring-Burn treatment. Considering that the Spring-Burn treatment increase in diversity was largely a function of increased annual forbs, it may not maintain higher levels of diversity over the long-term due to the ephemeral nature of annual forbs in this ecosystem (Bates 2004). The increase in diversity with prescribed burning followed by imazapic application suggests that ecosystem functions and resiliency may be improved with effective medusahead control and the establishment of perennial bunchgrasses. Decreased diversity can cause ecosystem nutrient losses, altered nutrient cycling, reduced carbon storage, and decreased ecosystem productivity (Tilman et al. 1997; Hooper and Vitousek 1998).

The effectiveness of the treatments applied to control medusahead may have been greater if the treatment plots were larger. The treatment plots were only $25 \mathrm{~m}^{2}$ and in the middle of medusahead infestations. Thus, medusahead propagule pressure from adjacent infested lands was probably high. Though the majority of medusahead seeds only disperse relatively short distances in the absence of vehicles and large animals (Davies 2008), over time propagule pressure would probably have been less in larger treated areas. Thus, larger treatment areas could increase the length of effective medusahead control thereby allowing seeded perennial bunchgrasses more time to become established before experiencing significant competition from medusahead.

\section{MANAGEMENT IMPLICATIONS}

The results of this study suggest that combinations of treatments provide the best control of medusahead and promote the establishment of seeded perennial bunchgrasses. These results likely apply to most invasive plants, but are probably especially relevant to other exotic annual grass invaders. In general, spring burning or fall burning prior to imazapic application were both successful treatments. This suggests that there are two windows of opportunity for prescribed burning prior to fall application of imazapic. Prescribed burning without imazapic application was not an effective control treatment and did not promote establishment of seeded perennial bunchgrasses. Imazapic application without prescribed burning did increase perennial bunchgrass cover, but without a significant increase in perennial bunchgrass density, it is doubtful that this treatment alone will effectively control medusahead and increase desired vegetation in the long-term. The results demonstrate that medusahead infestations can be successfully controlled and perennial bunchgrass can be established with prescribed burning followed by imazapic application. For establishment of perennial bunchgrasses, it appears that successful control of medusahead is critical. Because imazapic is used as a pre-emergent herbicide when applied in the fall to control medusahead, it is important to seed perennial bunchgrasses at least $1 \mathrm{yr}$ after treatment to reduce the probability of failure due to nontarget mortality of the perennial bunchgrass seedlings.

\section{ACKNOWLEDGMENTS}

The author thanks Dustin Johnson, Aleta Nafus, Brett Bingham, Karl Hopkins, Shawna Lang, Josh Monson, Matt Coffman, Eric Hough, Julie Garner, Tate Walters, Elaine Cramer, Rachel Svejcar, Stacy McKnight Johnson, Carrie Cimo, Ryan Morgan, and Jen Trenary for their assistance in implementing and collecting data for this experiment. The author also appreciates the landowners who allowed this study to be conducted on their property. The author is grateful to Drs Chad Boyd and Brenda Smith for reviewing earlier versions of this manuscript. The Eastern Oregon Agricultural Research Center is jointly funded by the US Department of Agriculture-Agricultural Research Service and Oregon State UniversityAgricultural Experiment Station.

\section{LITERATURE CITED}

BATES, J. 2004. Interannual productivity in burned and unburned Wyoming big sagebrush-grassland. In: Range field day report: current forage and livestock production research. Corvallis, OR, USA: Oregon State University Special Report 1052. p. 17-23.

Brooks, M. L., C. M. D’Antonio, D. M. Richardson, J. B. Grace, J. E. Keeley, J. M. Ditomaso, R. J. Hobbs, M. Pellant, and D. Pyke. 2004. Effect of invasive alien plants on fire regimes. BioScience 54:677-688.

Caldwell, M. M., D. M. Eissenstat, J. H. Richards, and M. F. Allen. 1985 Competition for phosphorus: differential uptake from dual-isotope-labeled soil interspaces between shrub and grass. Science 229:384-386.

Clausnitzer, D. W., M. M. Borman, and D. E. Johnson. 1999. Competition between Elymus elymoides and Taeniatherum caput-medusae. Weed Science 47: 720-728.

Cook, C. W. 1965. Grass seedling response to halogeton competition. Journal of Range Management 18:317-321.

D’Antonio, C. M., and P. M. Vitousek. 1992. Biological invasions by exotic grasses, the grass/fire cycle, and global change. Annual Reviews in Ecology and Systematics 23:63-87.

DAVIES, K. W. 2008. Medusahead dispersal and establishment in sagebrush steppe plant communities. Rangeland Ecology and Management 61:110-115. 
Davies, K. W., and J. D. Bates. 2010. Vegetation characteristics of mountain and Wyoming big sagebrush plant communities in the northern Great Basin. Rangeland Ecology and Management 63:461-466.

Davies, K. W., J. D. Bates, and R. F. Miller. 2006. Vegetation characteristics across part of the Wyoming big sagebrush alliance. Rangeland Ecology and Management 59:567-575.

Davies, K. W., J. D. Bates, and R. F. Miller. 2007a. Short-term effects of burning Wyoming big sagebrush steppe in southeast Oregon. Rangeland Ecology and Management 60:515-522.

Davies, K. W., M. L. Pokorny, R. L. Sheley, and J. J. James. 2007b. Influence of plant functional group removal on soil inorganic nitrogen concentrations in native grasslands. Rangeland Ecology and Management 60:304-310.

Davies, K. W., and R. L. Sheley. In press. Promoting native vegetation and diversity in exotic annual grass infestations. Restoration Ecology. DOI: 10.1111/j.1526-100X.2009.00548.x.

Davies, K. W., And T. J. SveJcar. 2008. Comparison of medusahead invaded and non-invaded Wyoming big sagebrush steppe in southeastern Oregon. Rangeland Ecology and Management 61:623-629.

Ditomaso, J. M., M. L. Brooks, E. B. Allen, R. Minnich, P. M. Rice, and G. B. Kyser. 2006. Control of invasive weeds with prescribed burning. Weed Technology 20:535-548.

Eissenstat, D. M., and M. M. Caldwell. 1987. Characteristics of successful competitors: an evaluation of potential growth rate in two cold desert tussock grasses. Oecologia 71:167-173.

Eiswerth, M. E., K. Krauter, S. R. Swanson, and M. Zielinski. 2009. Post-fire seeding on Wyoming big sagebrush ecological sites: regression analysis of seeded nonnative and native species densities. Journal of Environmental Management 90:1320-1325.

Goebel, C. J., M. Tazl, and G. A. HarRIs. 1988. Secar bluebunch wheatgrass as a competitor to medusahead. Journal of Range Management 41:88-89.

Gregg, M. A., J. K. Barnett, and J. A. Crawford. 2008. Temporal variation in diet and nutrition of preincubating greater sage-grouse. Rangeland Ecology and Management 61:535-542.

Hironaka, M., and B. W. Sindelar. 1973. Reproductive success of squirreltail in medusahead infested ranges. Journal of Range Management 26:219-221.

HiRonaka, M., AND B. W. Sindelar. 1975. Growth characteristics of squirreltail seedlings in competition with medusahead. Journal of Range Management 28:283-285.

Hironaka, M., and E. W. Tisdale. 1963. Secondary succession in annual grass vegetation in southern Idaho. Ecology 44:810-812.

Hooper, D. U., And P. M. Vitousek. 1998. Effects of plant composition and diversity on nutrient cycling. Ecological Monographs 68:121-149.

Hughes, F., P. M. Vitousek, And T. Tunison. 1991. Alien grass invasion and fire in the seasonal submontane zone of Hawaii. Ecology 72:743-746.

HuLL, A. C. 1974. Species for seeding arid rangeland in southern Idaho. Journal of Range Management 27:216-218.

James, J. J., K. W. Davies, R. L. Sheley, and Z. T. Aanderud. 2008. Linking nitrogen partitioning and species abundance to invasion resistance in the Great Basin. Oecologia 156:637-648.

Jones, T. A. 1998. Viewpoint: the present status and future prospects of squirreltail research. Journal of Range Management 51:326-331.

KreBS, C. J. 1998. Ecological methodology. 2nd ed. Menlo Park, CA, USA: Benjamin Cummings. $624 \mathrm{p}$.
Kyser, G. B., J. M. Ditomaso, M. P. Doran, S. B. Orloff, R. G. Wilson, D. L. Lancaster, D. F. Lile, and M. L. Porath. 2007. Control of medusahead (Taeniatherum caput-medusae) and other annual grasses with imazapic. Weed Technology 21:65-75.

Kyser, G. B., M. P. Doran, N. K. McDougald, S. B. Orloff, R. N. Vargas, R. G. Wilson, AND J. M. Ditomaso. 2008. Site characteristics determine the success of prescribed burning for medusahead (Taeniatherum caput-medusae) control. Invasive Plant Science and Management 1:376-384.

Lauenroth, W. K., J. L. Dodd, and P. L. Sims. 1978. The effects of water- and nitrogen-induced stresses on plant community structure in a semiarid grassland. Oecologia 36:211-222.

Littell, R. C., G. A. Milliken, W. W. Stroup, and R. D. Wolfinger. 1996. SAS System for Mixed Models. Cary, NC, USA: SAS Institute Inc. 633 p.

LiU, J., M. Dong, S. L. Miao, Z. Y. LI, M. H. Song, And R. Q. Wang. 2006. Invasive alien plants in China: role of clonality and geographical origin. Biological Invasions 8:1461-1470.

MAck, R. N. 1981. Invasion of Bromus tectorum L. into western North America: an ecological chronicle. Agro-Ecosystems 7:145-165.

Mıtton, S. 2004. Grasses as invasive alien plants in South Africa. South African Journal of Science 100:69-75.

Monaco, T. A., T. M. Osmond, And S. A. Dewey. 2005. Medusahead control with falland spring-applied herbicides in northern Utah foothills. Weed Technology 19:653-658.

Murphy, A. H., And W. C. Lusk. 1961. Timing of medusahead burns. California Agriculture 15:6-7.

Natural Resource Conservation Service. 2008. Soil survey. Available at: http:// websoilsurvey.nrcs.usda.gov/. Accessed 19 December 2008.

Oregon Climatic Service. 2009. OCS home page. Available at: http://www.ocs. oregonstate.edu/index.html. Accessed 1 September 2009.

Rafferty, D. L., AND J. A. Young. 2002. Cheatgrass competition and establishment of desert needlegrass seedlings. Journal of Range Management 55:70-72.

Sheley, R. L., M. F. Carpinelli, and K. J. Reever Morgan. 2007. Effects of imazapic on target and nontarget vegetation during revegetation. Weed Technology 21:1071-1081.

Tilman, D., C. L. Lehman, and K. T. Thomson. 1997. Plant diversity and ecosystem productivity: theoretical considerations. Proceedings of the National Academy of Sciences 94:1857-1861.

Torell, P. J., L. C. Erickson, and R. H. Haas. 1961. The medusahead problem in Idaho. Weeds 9:124-131.

Whisenant, S. G. 1990. Changing fire frequencies on Idaho's Snake River Plains: ecological and management implications. In: E. D. McArthur, E. M. Romney, S. D. Smith, and P. T. Tueller [EDS.]. Cheatgrass invasion, shrub die-off, and other aspects of shrub biology and management. Ogden, UT, USA: USDA Forest Service, Intermountain Research Station. p. 4-10.

Young, J. A. 1992. Ecology and management of medusahead (Taeniatherum caput-medusae ssp. asperum [SIMK.] Melderis). Great Basin Naturalist 52:245-252.

Young, J. A., R. A. Evans, and J. Robinson. 1972. Influence of repeated annual burning on a medusahead community. Journal of Range Management 25:372-375.

Young, K., And J. Mangold. 2008. Medusahead outperforms squirreltail through interference and growth rate. Invasive Plant Science and Management 1:73-81. 